\title{
Vas Deferens Surface Epithelium of Agouti paca: Fine Structural Features
}

\author{
Epitelio del Conducto Deferente de Agoutipaca. Observaciones de Estructura Fina
}

\begin{abstract}
"Antonio M. Orsi; ** Karina Simões; "Raquel F. Domeniconi; ${ }^{* * *}$ Claudinei da Cruz; ${ }^{* * * * *}$ Márcia R. F. Machado \& "Joffre G. Filho
\end{abstract}
ORSI, A. M.; SIMOES, K.; DOMENICONI, R. F.; DA CRUZ, C.; MACHADO, M. R. F. \& FILHO, J. G. Vas deferens surface epithelium of Agouti paca: fine structural features. Int. J. Morphol., 27(1):89-96, 2009.

SUMMARY: The surface epithelium of the vas deferens of Agouti paca, a wild and large South American rodent, was basically formed by principal and basal cells being only the principal cells related to endocytosis processes and also secretion taking base on their cytoplasmic ultrastructural features. Principal cell of vas deferens epithelium were characterized mainly by presence of vesicles with several shapes, sizes and internalized content at their apical cytoplasm occurring smaller pits and pale small vesicles seen next to the apical brush border of microvillus. Moreover, coated vesicles, smooth surface vesicles and great vesicles; multivesicular bodies, endosomes and lysosomes were seen. Presence of an apocrine secretory apparatus was also viewed, showing apical cytoplasmic expansions protruding into the vas deferens luminal compartment. The basal flattened cells, without luminal surface contact, occurred next to the basement membrane of the ductus, and did no exhibit special ultrastructural features.

KEY WORDS: Vas deferens epithelium; Fine structure; Histophysiology; South American rodent.

\section{INTRODUCTION}

The vas deferens of mammals helps to guarantee two steps of the sperm transport into the lumen of the excurrent ducts of the testis known as emission and ejaculation (Pabst et al., 1969; Baumgarten et al., 1971; Hib et al., 1982; DiDio \& Leão, 2002; Orsi et al., 2002). During the emission, the seminal fluid with spermatozoa is expelled from the testicular tubules to the luminal compartment of the epididymidis, whose distal part (cauda epididymidis) undergoes violent contraction (Pabst et al.). Then spermatozoa and luminal fluid pass to the lumen of the vas deferens through short and potent peristaltic smooth muscle cells contractions of the ductal walls (Pabst et al.; Baumgarten et al.; DiDio \& Leão). Storage of spermatozoa in the ampullar or distal part of the vas deferens has also been described (Hib et al.). These functional roles find an adequate structural support. which has been also analyzed by scanning electron microscopy in the vas deferens of the gerbil (Orsi et al., 1999). Moreover the vas deferens of mammals, with emphasis on laboratory rodents, plays other roles through the functional activity of epithelial lining cells such as adsorptive endocytosis (or phagocytosis), and phase-fluid endocytosis (or pinocytosis), (Hermo \& De Melo, 1987; Clermont, 1993; Hermo et al., 1994; Domeniconi et al., 2007) synthesis and secretion of proteins (Hermo \& De Melo; Robaire \& Hermo, 1988; Hermo et al., 1994; Orsi et al., 1999; Domeniconi et al.), and apocrine secretion (Manin et al., 1995; Orsi et al., 1998).

Agouti paca, or vulgarly "paca or laca" is the second largest rodent in the neotropical region after the capybara, having a large zootechinic potential because its meat is highly appreciated for human feeding (Mondolfi, 1972; Matamoros, 1982). The "paca" belongs to the family Agoutidae, genus Agouti, which together with the families Caviidae, Hydrochoeridae and Dasyproctidae, form the group of the histricognath rodents in the New World (Eisenberg, 1989). Some studies had compared the ultrastructure and epithelium

* Departmento de Anatomia/ UNESP, Campus de Botucatu, SP, Brasil.

* Centro Universitário de São José do Rio Preto, SP, Brasil.

**** Bolsista de Pós-Doutorado/ UNESP, Campus de Jaboticabal, SP, Brasil.

***** Departmento de Morfologia e Fisiologia Animal/ UNESP, Campus de Jaboticabal, SP, Brasil.

FAPESP, processos $\mathrm{N}^{\circ}$ 01/14984-5 and 03/00879-0. 
cells physiology features of the vas deferens, specially among the man and laboratory rodents with some supporting references could be found (Hermo \& De Melo; Robaire \& Hermo; Hermo et al., 1994; Manin et al.; Orsi et al., 1999; Orsi et al., 2002; DiDio \& Leão). Based on these theoretical support, the target of this study was to analyze the ultrastructure and cell morphophysiological features of the lining epithelium of the vas deferens of adult Agouti paca. Also this communication aimed to compare the observations made on the deferential surface epithelium of the "paca" with the morphologic features of the vas deferens previous reported to other mammalian species.

\section{MATERIAL AND METHOD}

Ultrastructural analysis of the middle segment of the vas deferens was made in materials collected from 6 male adult "pacas" (Agouti paca) proceeding from the Sector of Wild Animals, Department of Animal Zootechny, School of Agriculture and Veterinary of UNESP at Jaboticabal, SP, Brazil. The rodents suffered euthanasia with intramuscularly administration of Azaperone ${ }^{\circledR}(4 \mathrm{mg} / \mathrm{kg})$, followed by sedative narcosis with a mixture of ketamine hydrochloride $(20 \mathrm{mg} / \mathrm{kg})$ and xylazine hydrochloride $(1.5 \mathrm{mg} / \mathrm{kg})$, applied intramuscularly. Tissue fragments were collected from the middle ("spermatic funicular") segment of each rodent vas deferens, fixed in 2.5\% 0.1 M glutaraldehyde (Merck ${ }^{\mathrm{TM}}$ ) in sodium phosphate buffer, $\mathrm{pH}$ 7.2, or in Karnovsky's fixative during 3 hours, at $4^{\circ} \mathrm{C}$. After convenient reduction, the specimens were postfixed in $1 \% \mathrm{OsO}_{4}\left(\mathrm{Merck}^{\mathrm{TM}}\right)$, in the same buffer. Following tissue fixation, the tissue samples were dehydrated in an increasing acetone series and embedded in Araldite ${ }^{\circledR}$ (Merck, Germany). The blocks were trimmed and cut into semi-thin sections $(0.5 \mu \mathrm{m})$ and ultrathin sections (80 $\mathrm{nm}$ on average). Ultrathin sections were mounted on copper grids, stained with uranyl acetate and lead citrate, and analyzed and photographed under a Philips CEM-100 (Philips ${ }^{\circledR}$, The Netherlands) transmission electron microscope at the Electron Microscopy Center of UNESP at Botucatu, São Paulo, Brazil.

\section{RESULTS}

The supranuclear cytoplasm of the principal cells in the lining epithelium of Agouti paca vas deferens showed at ultrastructural level a well-developed endocytotic apparatus characterized by presence of a large number of lysosomes disposed adjacent to multivesicular bodies with pale or denser content, and by occurrence of endosomes. Vesicles of varia- ble shapes and sizes, small coated and dense vesicles; smooth surface pale vesicles and adjacent mitochondria were also verified (Figs. 1 to 3). Rough endoplasmic reticulum (RER) cisternae were observed in the supranuclear and apical cytoplasm. The RER consisted of long lamellae containing a large number of ribosomes adhering to their lamellar walls and near of adjacent free ribosomes, forming polysomes. Intermediate filaments were observed close to the RER lamellae adjacent to vesicles of variable feature, shape and size (Figs. 1 and 3). At the supranuclear cytoplasm some principal cells presented yet large lipid inclusions, surrounded by endomembranes (Fig. 4), and in the lateral plasmatic membranes interdigitations were seen (Fig. 3).

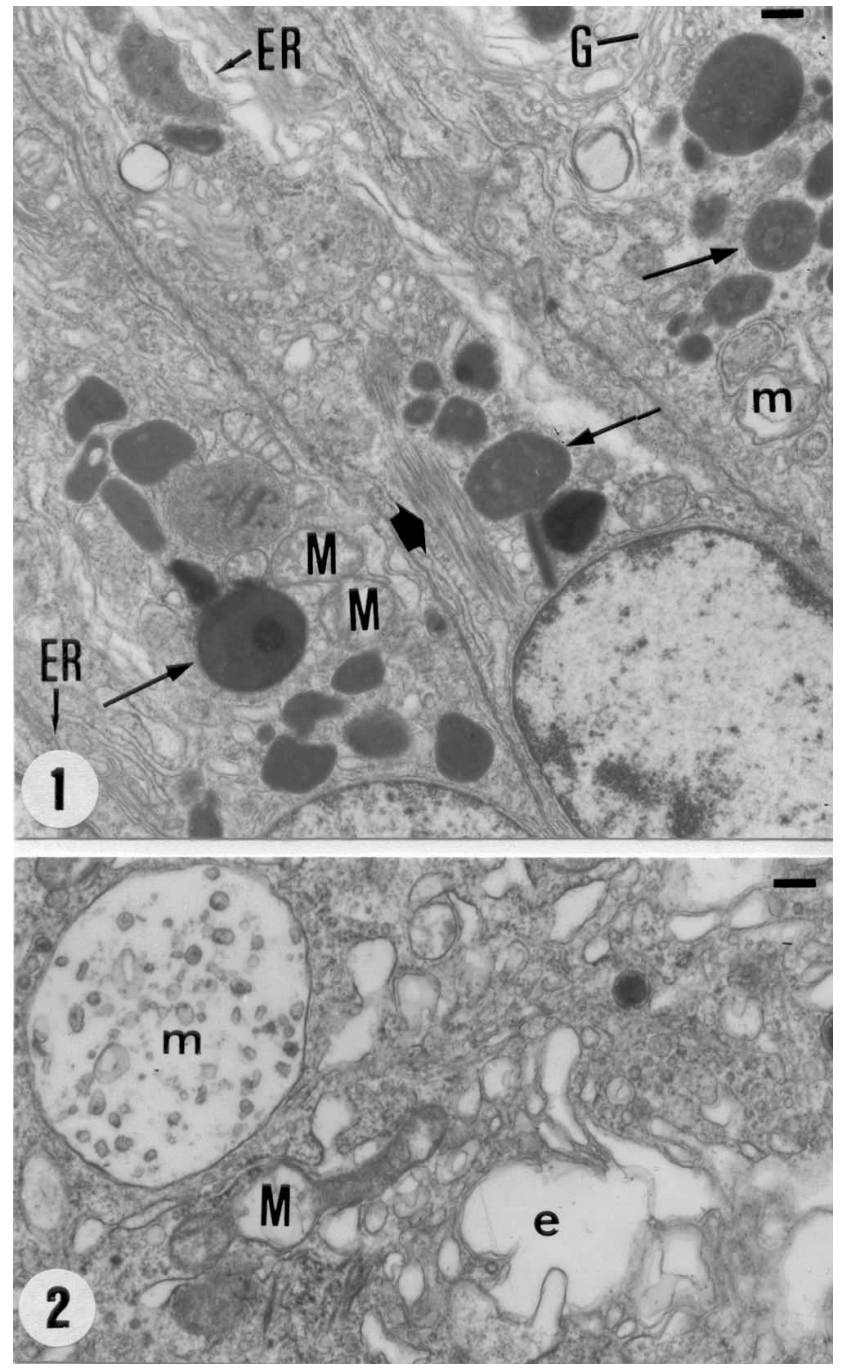

Figs. 1 and 2. Ultrastructure of principal cells of the lining epithelium of the vas deferens of the adult Agouti paca at the level of the supranuclear cytoplasm showing the Golgi apparatus $(\mathrm{G})$, endoplasmic reticulum (ER, mainly rough), lysosomes (arrows), multivesicular bodies (m), mitochondria (M), and intermediate filaments (thick arrow). Note the large number of variable vesicles in the cytoplasm and one endosome (e). 1 : bar $=0.4 \mu \mathrm{m} / 2:$ bar $=$ $0.22 \mu \mathrm{m}$. 

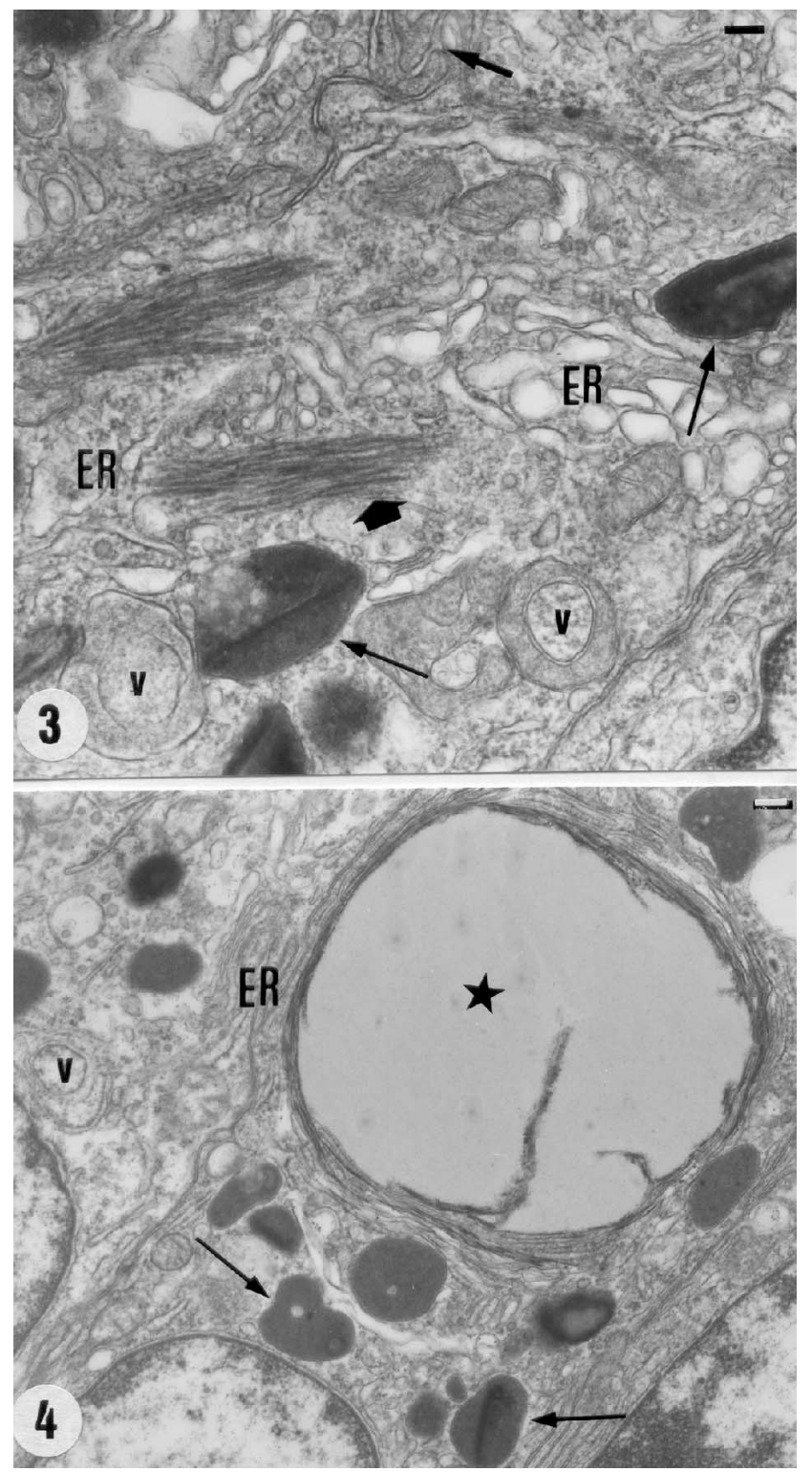

Figs. 3 and 4. Supranuclear cytoplasm of principal cells of the vas deferens showing rough endoplasmic reticulum (ER), intermediate filaments (thick arrow), lysosomes (long arrows), double coated vesicles (v), and a large lipid inclusion (star). Note the large number of vesicles with variable sizes, shapes and content mainly near the ER. 3 : bar $=0.16 \mu \mathrm{m} / 4$ : bar $=0.3 \mu \mathrm{m}$.

Caveolae in the apical cytoplasmic membrane, as well as coated pits and mainly transparent vesicles, multivesicular bodies and lysosomes occurred in the apical cytoplasm of principal cells close related to the apical brush border (microvilli), allowing support to characterize a process of endocytosis (Figs 5 and 6). Microtubules and canaliculated tubule of the apical $\mathrm{T}$ system, as well as intimal endomembrane complexes, apically disposed, were seen between the lateral plasma membranes of adjacent
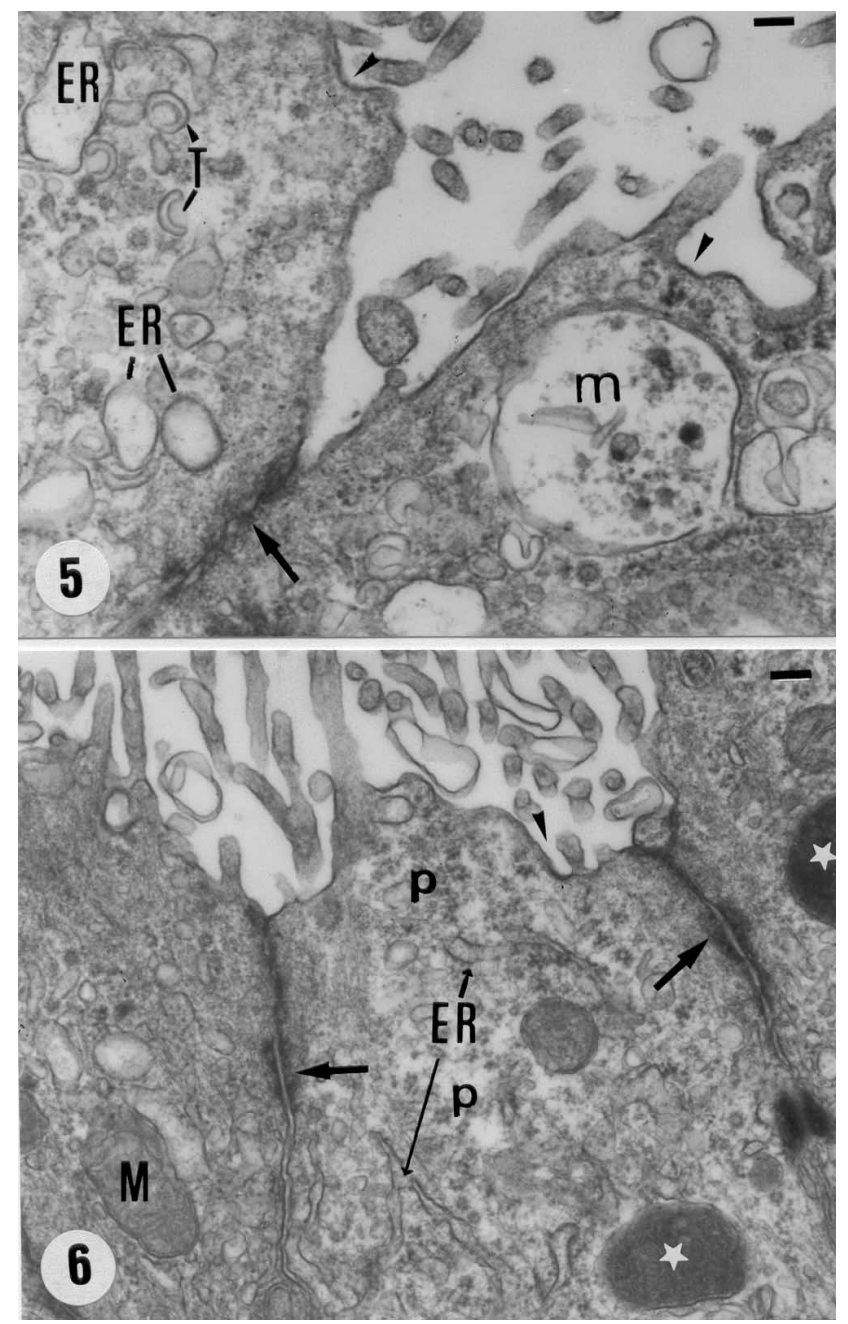

Figs. 5 and 6. Apical cytoplasm of principal cells showing cisterns and lamellae of rough endoplasmic reticulum (ER), polysomes (p), apical tubular structures (T), junctional complexes (arrows), caveolae (arrowheads), multivesicular body (m), mitochondria (M) and lysosomes (white stars). Note the large number of apical vesicles with variable sizes, shapes and content. 5 : bar $=0.12 \mu \mathrm{m} / 6: \mathrm{bar}=$ $0.23 \mu \mathrm{m}$.

principal cells (Fig. 5). Moreover, RER cisternae extended into the apical cytoplasm and polysomes and small dense coated vesicles were observed (Figs. 5 and 6). "Complex multivesicular bodies" engulfing dense bodies with different electron densities, as well as small pale and circumscribed vesicles were seen in the basal cytoplasm of some principal cells (Fig. 7).

Basal cells were found next to the basal cytoplasm of adjacent principal cells, and near the tubular basement membrane, which delimited the lamina propria of the vas deferens. Basal cells appeared elongated, mainly pyramidal in shape and contained a few cytoplasmic organelles. Their 
nuclei were elongated with a notched nuclear envelope. Euchromatin predominated in the nuclear matrix in having heterochromatic flakes adhered to the nuclear envelope (Fig. 7).

The apical cytoplasm of some principal cells was characterized by prominent apical cytoplasmic expansions projecting into the tubular lumen through the apical brush border (Figs. 8 and 9). Globular formations showing feature of pale multivesicular bodies, sometimes engulfing denser material of the cytoplasmic matrix, as well as small dense vesicles and dense granular material, were verified in the cytoplasm of the apical expansions (Figs. 8 and 9). On the apical cytoplasm of some principal cells, the rough ER appeared circumferential with its lamellae being arranged in a concentric and parallel disposition, delimiting a homogenous and denser part of the cytoplasmic matrix or dense granules. Variable vesicles, mitochondria, multivesicular bodies and lysosomes surrounding the concentric lamellae of the RER were also seen (Fig. 10). The vas deferens lumen showed some spermatozoa nearing the luminal brush border of microvilli (Fig. 11).

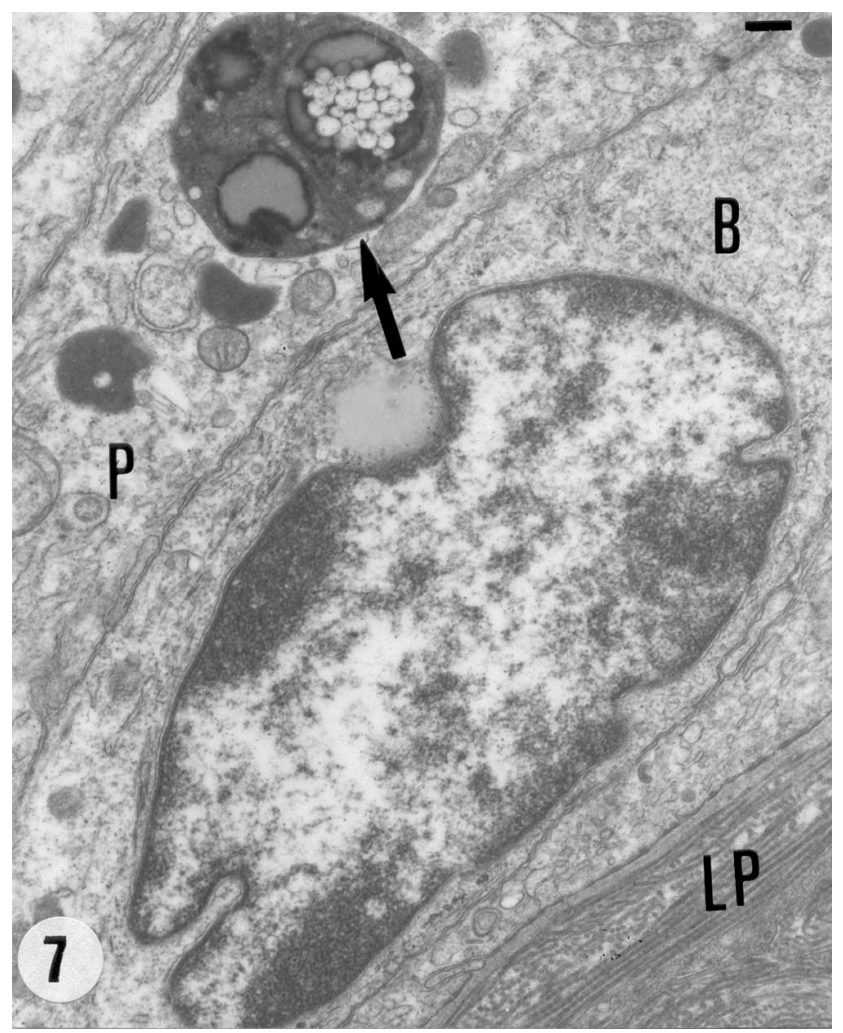

Fig. 7. Basal cell (B) with scarcity of cytoplasmic organelles, underlying the basal cytoplasm of a principal cell $(\mathrm{P})$ and disposed near of the lamina propria (LP) of the vas deferens, also showing complex multivesicular body (arrow) at the basal cytoplasm of the P cell. 7: $b a r=0.3 \mu \mathrm{m}$.
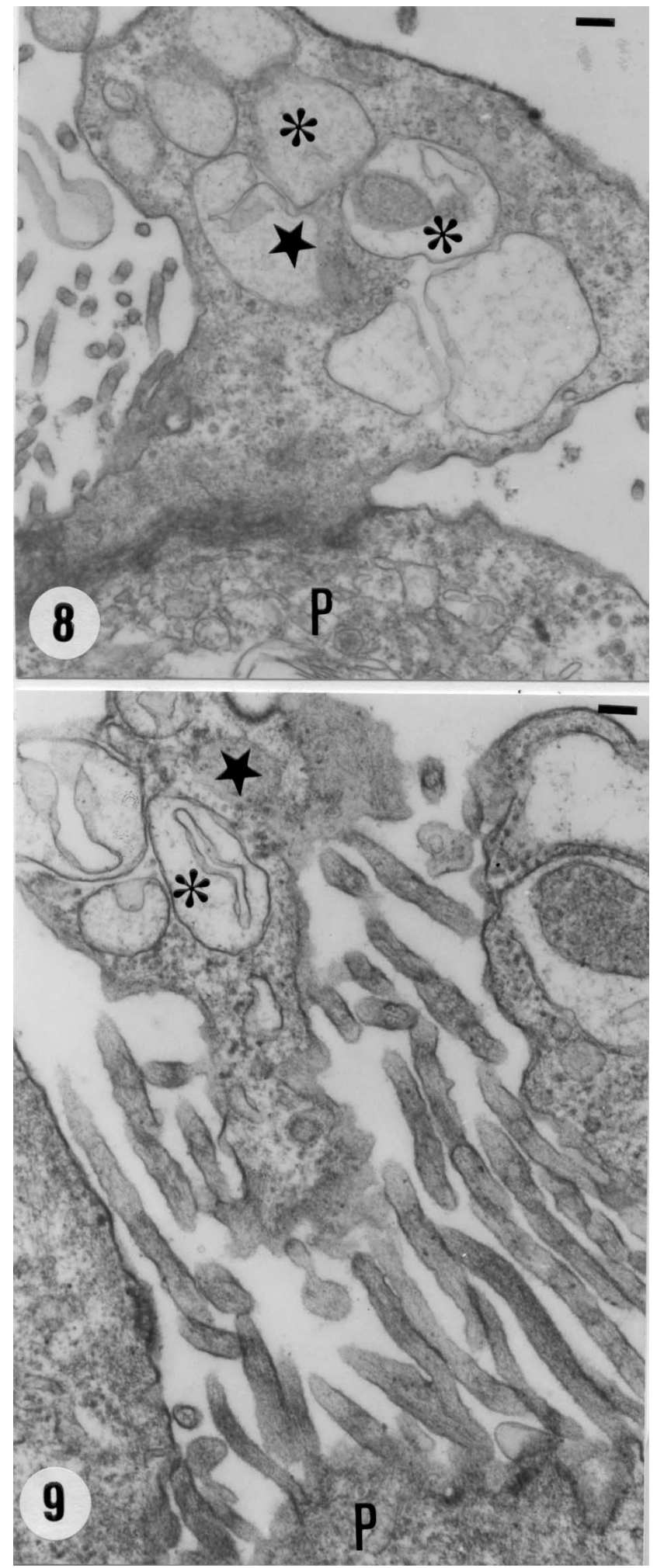

Figs. 8 and 9. Apical cytoplasmic expansions (stars) of P cells projecting into the tubular lumen and surrounded by apical microvilli, having pale multivesicular bodies (*) inside the expansions. 8 : $\mathrm{bar}=0.22 \mu \mathrm{m} / 9 \mathrm{bar}=0.12 \mu \mathrm{m}$. 
Spermatozoa presented inside the vas deferens lumen of "paca", perhaps had been correlated to processes of emission and storage of spermatozoa, which occurred as part of the luminal compartment histophysiology, mainly into the myoconnective ductal structure of the vas deferens.

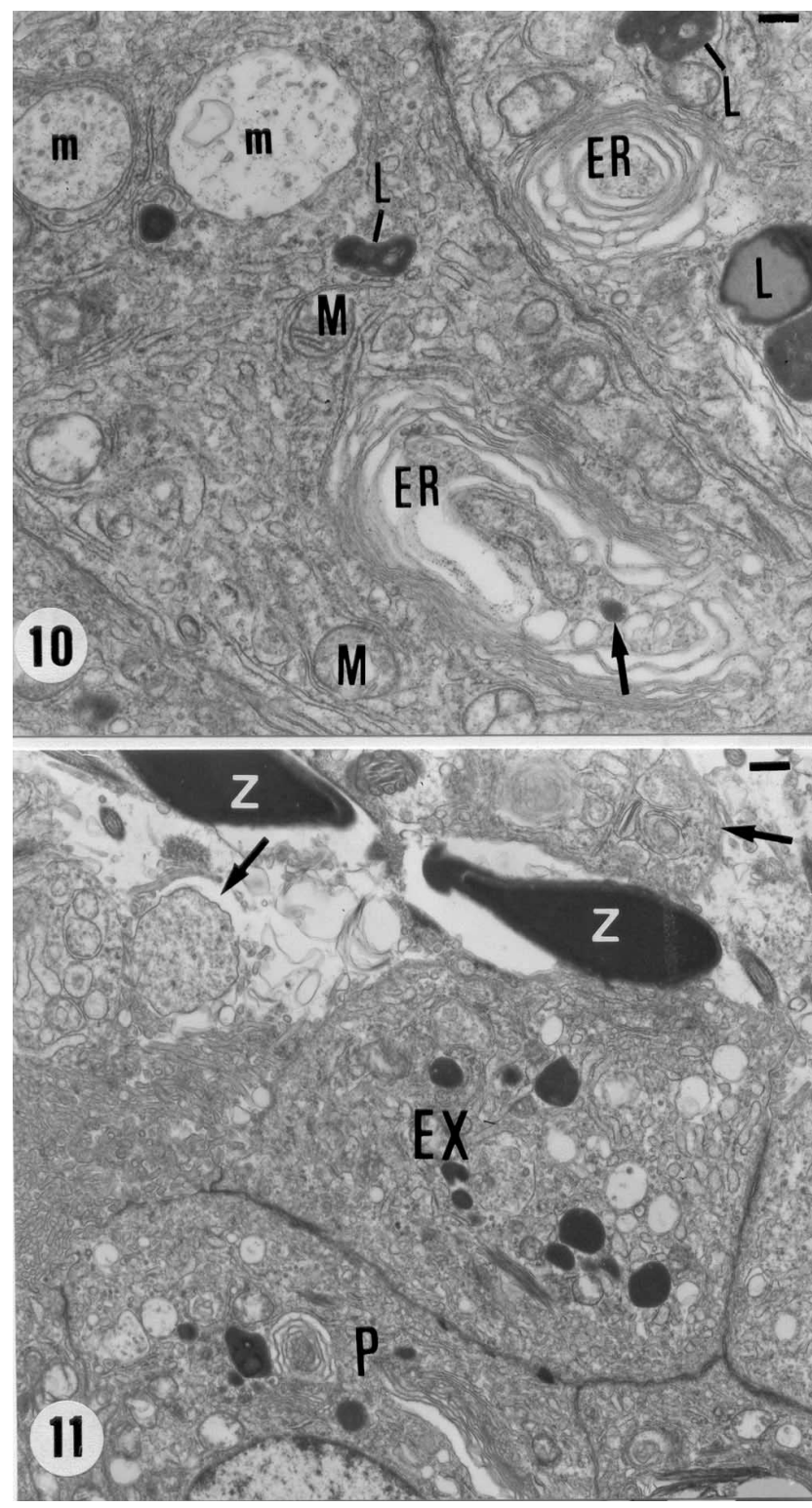

Fig. 10. Apical cytoplasm of P cells showing concentric rough endoplasmic reticulum (ER), containing a dense granule (arrow); multivesicular bodies (m) and lysosomes (L). Also sectioned structures of intraluminal spermatozoa $(Z)$ were seen into the vas deferens lumen, near the apical border of $\mathrm{P}$ cells and related to a fixed cytoplasmic expansion (EX) and cytoplasmic expansions detached into the lumen (arrow). Note the large number of vesicles with variable sizes, shapes and content. 10 and 11 : bars $=0.3 \mu \mathrm{m}$, respectively.

\section{DISCUSSION}

The supranuclear cytoplasm of the epithelium principal cells of Agouti paca vas deferens was marked by a well-developed endocytotic apparatus, with possible occurrence of adsorptive endocytosis and phase-fluid endocytosis, similarly to the same process previous described in other cells (Goldstein et al., 1979), and in principal cells of the vas deferens and ductus epididymis of other laboratory rodents (Hermo \& De Melo; Robaire \& Hermo; Hermo et al.,1992, 1994; Orsi et al., 1994, 1999; Domeniconi et al.), and in a domestic bird (Stefanini et al., 1999). Endocytotic activities verified in the lining epithelium of the paca's vas deferens had been quite similar to those described for principal cells of the rat vas deferens and also in Sertoli cells of the testis (Clermont, 1993; Hermo et al., 1994).

Endocytosis activities in principal cells of the paca's vas deferens were characterized here mainly on the supranuclear and apical cytoplasmic levels, such as described in the vas deferens, efferent ducts and epididymal duct of other mammals (Hermo \& De Melo; Robaire \& Hermo; Hermo et al.,1992, 1994; Orsi et al., 1994, 1998, 1999; Domeniconi et al.). Subcellular structures involved in these activities, at the excurrent ducts of the testis level, in several species, included pits, coated vesicles and smooth surface vesicles with different shapes and sizes showing a predominantly pale content; endosomes, pale and dense multivesicular bodies, and lysosomes as previously characterized to some animal cells (Goldstein et al.), and verified on the epithelium compartment of the excurrent ducts of the testis (Robaire \& Hermo), including the species also cited in this paper.

The first steps of the endocytotic process, which occurred in principal cells of the vas deferens were, marked by presence of caveolae formed among the microvillus of the apical brush border. Sequentially the subjacent apical plasmatic membrane internalized those caveolae forming small coated vesicles into the apical cytoplasm, as firstly characterized (Goldstein et al.). Moreover, the course of the endocytotic process in paca's vas deferens lining epithelium was characterized by presence of the other subcellular structures interrelated with this process, according to our results, and previous descriptions in principal cells of the excurrent ducts of the testis (Hermo et al., 1994; Orsi et al., 1998, 1999; Domeniconi et al.).

So, endosomes, multivesicular bodies and lysosomes were seen into the supranuclear and apical cytoplasm of principal cells of the paca's vas deferens being organelles, whose presence could support occurrence of endocytosis, according the previous base reported before. Similar patterns were also 
detected in the vas deferens principal cells of albino rat (Hamilton, 1975; Hermo \& De Melo; Robaire \& Hermo; Hermo et al., 1992,1994) and in principal cells of the epithelial lining of excurrent ducts of the testis in Mongolian gerbil (Orsi et al., 1999; Domeniconi et al.). On the other hand, the possible occurrence of autophagic or heterophagic digestive processes in principal cells of the vas deferens in paca could be suggested, based on the observations made in this study, and supported by theoretical data regarding similar processes characterized on the general morphology of the Sertoli cells of the testis (Clermont).

Another marked observation on the cytoplasmic ultrastructure of principal cells of the paca's vas deferens was the occurrence of concentric and parallel lamellae of the RER disposed apically. These lamellae delimited a space of the cytoplasmic matrix that sometimes contained dense granules (see Figure 10), supporting the hypothesis of synthesis and deportation of protein material, based also on previous subcellular observations of principal cells of the epididymis of domestic pig (Briz et al., 1993), and in the vas deferens of gerbil (Orsi et al., 1999). So, a similar cell morphophysiologic role proposed in this study had been also proposed in the previous cited reports.

Secretory activity in principal cells of vas deferens, together with observations regarding the subcellular appearance of the Golgi apparatus and RER presented in the apical cytoplasm of principal cells of vas deferens of "paca" effectively supported the occurrence of protein (or glycoprotein) secretion in the vas deferens, as previously described for the epididymidis of albino mouse (Flickinger, 1983, 1985), and for the black isogenic mouse (Orsi et al., 1994). Additionally, secretory functions were proposed for principal cells of the vas deferens of albino rat (Hamilton; Hermo \& De Melo; Robaire \& Hermo; Hermo et al.,1992, 1994), as well as for epididymidis principal cell of Mongolian gerbil (Domeniconi et al.).

Concerning to the apical cytoplasmic expansions observed in principal cells of vas deferens epithelium of paca, some of them extruded into the tubular lumen and they perhaps might be characterized as appocrine secretion, similarly to observations made in principal cells from the cat epididymis (Morales \& Cavicchia, 1991; Viotto et al., 1996), in vas deferens epithelium cells of rodents (Manin et al.; Orsi et al., 1999), and also in principal cells of the efferent ducts of pigeon (Stefanini et al.).

With respect to basal cell ultrastructure, also verified in the vas deferens epithelium of Agouti paca, this cell type had been considered a possible differentiation phase of the epididymidis cell population (Briz et al.). This morphofunctional interpretation on basal cells had been applied to both proximal and more distal segments of the excurrent ducts of the testis (Robaire \& Hermo; Hermo et al., 1994). Basal cells also had been considered as stabilizing cellular elements of the epithelium structure, acting at the basal epithelium level and anchoring the basal cytoplasm of adjacent principal cells ones with the others (Hamilton).

Some lipid inclusions viewed in the supranuclear cytoplasm of principal cells of the vas deferens of "paca" perhaps represented a functional reservoir for these cells. Nevertheless, reports regarding to cholesterol synthesis and steroid function in the spermatic ducts, more specifically in the epididymis in loco (Hamilton; Robaire \& Hermo), had suggested that the supply of lipids included free fatty acids derived from the blood stream to satisfy the acetate metabolic pathway (Eik-nes, 1975; Hamilton; Robaire \& Hermo).

To finalize, concerning to the spermatozoa presented inside the vas deferens lumen of "paca", as was verified in other mammalian species (Hamilton; Hib et al.; Robaire \& Hermo; Nistal et al;. 1992; Hermo et al., 1992, 1994; Orsi et al., 1999, 2002; DiDio \& Leão), perhaps spermatozoa presented a direct correlation with the processes of emission and storage of spermatozoa, described by Hib et al., having a previous support in Pabst (1969) investigations on the human vas deferens morphology. Both processes occurred as part of the luminal compartment histophysiology, mainly into the myoconnective ductal structure of the vas deferens, as had been reported by the last authors cited.

In conclusion the principal cells of the vas deferens of Agouti paca were closely related to processes of adsorptive endocytosis, phase-fluid endocytosis and secretion taking base on their cytoplasmic ultrastructural features. Principal cells were marked by presence of vesicles of several shapes, sizes and some of them having internalized content. Also occurred caveolae, smaller pits and pale small vesicles localized next to the apical brush border of microvillus as well as coated vesicles, smooth surface vesicles and great vesicles were seen. Multivesicular bodies, endosomes and lysosomes were observed mainly in an apical position. Furthermore, occurrence of an apocrine secretory process was verified through the occurrence of apical cytoplasmic protrusions viewed inside the vas deferens luminal compartment. Basal flattened cells occurred next to the ductal basement membrane, not exhibiting marked special subcellular features.

ACKNOWLEDGMENT. The authors thank the technical support obtained at the "Centro de Microscopia Eletronica of UNESP at Botucatu. 
ORSI, A. M.; SIMOES, K.; DOMENICONI, R. F.; DA CRUZ, C.; MACHADO, M. R. F. \& FILHO, J. G. Epitelio del conducto deferente de Agouti paca. Observaciones de estructura fina. Int. J. Morphol., 27(1):89-96, 2009.

RESUMEN: El epitelio que recubre la luz del conducto deferente de la laca (Agouti paca), un roedor silvestre de Sudamérica, está formado por células principales (P) y basales (B), en donde las células principales están asociadas a los procesos de endocitosis y secreción, teniendo una base en su característica ultraestructural citoplasmática. Las células principales de los vasos deferentes del epitelio se caracteriza principalmente por la presencia de vesículas con variadas formas, tamaños y contenido interior en su citoplasma apical produciendo pequeñas invaginaciones y pequeñas vesículas pálidas ubicadas contínuas al borde en cepillo de las microvellosidades apicales. Además, fueron observados, vesículas de superficie lisa y vesículas de gran tamaño; órganos multivesiculares, endosomas y lisosomas. También se observó la presencia de un aparato secretor apocrino, con expansiones citoplasmáticas apicales que se protruyen en el compartimiento luminar del conducto deferente. Células basales aplanadas, sin contacto con la superficie luminal, se encuentran junto a la membrana basal del conducto, las que no presentan características ultraestructurales especiales.

PALABRAS CLAVE: Epitelio del conducto deferente; Estructura fina; Histofisiología; Roedor sudamericano.

\section{REFERENCES}

Baumgarten, H. G.; Holstein, A. F. \& Rosengren, E. Arrangement, ultrastructure and adrenergic innervation of smooth musculature of the ductuli efferentes, ductus epididymidis and ductus deferens of man. Z. Zellforsch. mikrosk. Anat., 120:37-79, 1971.

Briz, M.; Bonet, S. \& Fradera, A. A Morphologic study of the ducts of the epididymis of Sus domesticus. J. Morphol., 215:183-93, 1993.

Clermont, Y. Introduction to the Sertoli Cell. In: Russel, L. D. \& Griswood, M. D. (Ed.). The Sertoli Cell. Clearwater, Cache River Press,1993. p.899.

DiDio, L. J. A. \& Leão, P. P. Sistema genital masculino. In: DiDio, L. J. A. Tratado de Anatomia Sistêmica e Aplicada. São Paulo, Ed. Atheneu, 2002. pp.621-52.

Domeniconi, R. F.; Orsi, A. M.; Beu, C. C. L. \& Felisbino, S. L. Morphological features of the epididymal epithelium of gerbil, Meriones unguiculatus. Tiss. Cell, 39:47-57, 2007.

Eik-Nes, K. B. Biosynthesis and secretion of testicular steroids. In: Greep, R. O. \& Astwood, E. B. (eds.) Handbook of Physiology: Male reproductive system. Washington, American Physiology Society, 5:95-116, 1975.

Eisenberg J. F. Mammals of the neotropics: the northern neotropics. Chicago, The University of Chicago Press, 1989.

Flickinger, C. J. Autoradiographic analysis of the secretory pathway of glycoprotein in principal cells of the mouse epididymis exposed to H3-fucose. Biol. Reprod., 32:377$89,1985$.
Flickinger, C. J. Autoradiographic analysis of the secretory pathway of glycoprotein in principal cells of the mouse epididymis exposed to $\mathrm{H} 3$-fucose. Biol. Reprod., 32:377-89, 1985.

Goldstein, J. L.; Anderson, R. G. W. \& Brown, M. S. Coated pits, coated vesicles and receptor mediated endocytosis. Nature, 279:679-85, 1979.

Hamilton D. W. Structure and function of the epithelium lining the ductuli efferentes, ductus epididymidis, and ductus deferens in the rat. In: Greep, R. O. \& Astwood, E. B. (eds.). Handbook of Physiology: Male reproductive system. Washington, American Physiology Society, 5:259-302, 1975.

Hermo, L.; Barin, K. \& Robaire, B. Structural differentiation of the epithelial cells of the testicular excurrent duct system of rats, during postnatal development. Anat. Rec., 233:205-28, 1992.

Hermo, L. \& De Melo, V. R. Endocytotic apparatus and transcytosis in epithelial cells of the vas deferens in the rat. Anat. Rec., 217:153-63,1987.

Hermo, L.; Oko, R. \& Morales, C. Secretion and endocytosis in the male reproductive tract: A role in sperm maturation. Int. Rev. Cytol., 154:105-89,1994.

Hib, J.; Ponzio, R. \& Villar, O. Contractility of the rat cauda epididymidis and vas deferens during seminal emission. J. Reprod. Fertil., 66:47-50, 1982.

Manin, M.; Lecher, P.; Martinez, A; Tournadre S. \& Jean, C. Exportation of mouse vas deferens protein, a protein without a signal from vas deferens epithelium: a model 
ORSI, A. M.; SIMOES, K.; DOMENICONI, R. F.; DA CRUZ, C.; MACHADO, M. R. F. \& FILHO, J. G. Vas deferens surface epithelium of Agouti paca: fine structural features. Int. J. Morphol., 27(1):89-96, 2009.

of apocrine secretion. Biol. Reprod., 52:50-62, 1995.

Matamoros, Y. Investigaciones preliminares sobre la reproducción, comportamiento, alimentación y manejo tepezcuinte (Cuniculus paca), en cautiverio. In: Congreso Latinoamericano de Zoología. Anales, 1:961-92, 1982.

Mondolfi, E. La laca o paca: defensa de la naturaleza. Acta Biol. Venezuelica, 2(5):4-16, 1972.

Morales, A. \& Cavicchia, J. C. Release of cytoplasmic apical protrusions from principal cells of the cat epididymis: An electron microscopic study. Tiss. Cell, 23:505-13, 1991.

Nistal, M.; Santamaria, L. \& Paniagua, R. The ampulla of the ductus deferens in man: Morphological and ultrastructural aspects. J. Anat., 180:97-104, 1992.

Orsi, A. M.; Matheus, S. M. M.; Farje, L. A. D. F.; Orsi, D. C. \& Artoni, S. M. B. Estudio por microscopía electrónica de barrido de la estructura del conducto deferente del gerbo (Meriones unguiculatus). Acta Biol. Venezuelica, 20:29-33, 2002.

Orsi, A. M.; Matheus, S. M. M.; Gregorio, E. A. \& Beu, C. C. L. Morphological investigations on the surface epithelium of ductuli efferentes of black isogenic mice (Mus musculus). Anat. Histol. Embryol., 27:215-8, 1998.

Orsi, A. M.; Matheus, S. M. M.; Stefanini, M. A.; Vicentini, C. A.; Ribeiro, A. A. C. M. \& Miglino, M. A. Fine structure of the lining epithelium of the ductus deferens in gerbil, a segmental study. Braz. J. Morphol. Sci., 16:189-95, 1999.

Orsi, A. M.; Vicentini, C. A.; Vicentini, I. B. F.; Stefanini, M. A. \& Orsi, A. C. Ultrastructure of epididymal epithelium of the black isogenic mouse. Rev. Chil. Anat., 12:189-96, 1994.

Pabst, R. Untersuchungen über Bau und Funktion des menschilichen Semenleiters. Z. Anat. Entwickl. Gesch., 129:154-76, 1969.

Robaire, B. \& Hermo, L. Efferent ducts, epididymis, and vas deferens structure, functions, and their regulation. In: Knobil, E. \& Neill, D. J. (Eds.). Physiology of Reproduction. New York, Raven Press Ed., 1988. pp.999-1080.
Stefanini, M. A.; Orsi, A. M.; Gregorio, E. A. \& Viotto, M. J. S. Morphologic study of the efferent ducts of the pigeon (Columba livia). J. Morphol., 242:247-55, 1999.

Viotto, M. J. S.; Orsi, A. M. \& Gregorio, E. A. Ultrastructural characteristics of epididymal epithelium of the cat (Felis domestica). Braz. J. Morphol. Sci., 13:51-8, 1996.

Correspondence to: Dr. Antonio Marcos Orsi Departmento de Anatomia/ UNESP Campus de Botucatu, SP, Brasil.

Email: amorsi@ibb.unesp.br

Received: 09-07-2008

Accepted: 26-10-2008 